\title{
Do Diversity and Bio-morphological Spectrum of Psammophytes Matter in Restoring Vegetation of Sand Pits?
}

\author{
Alaa Dabbagh* \\ Peoples' Friendship University of Russia (RUDN University), Faculty of Ecology, 6 Miklukho- \\ Maklaya St, Moscow, 117198, Russian Federation
}

\begin{abstract}
Open mining of sand is executed in the sand pits. After completion of the work sand pits are usually recultivated: firstly they are graded and then planted with trees and shrubs, but very often sand pits are abandoned to regenerate themselves. The sand pit becomes a source of dust and a hardly healed wound on the earth's body. In order to provide an adequate revegetation on such substrates, it is necessary to study biomorphological peculiarities of growing plants in a very specific environment characterized by high stiffness of slopes and high mobility of the substrate. The material for our study collected from Moscow Region sand pits in the Russian federation. Plants were collected from both northern and southern exposure slopes. Our work is based on the geobotanical descriptions made according to standard method on experimental sites of $5 \times 5 \mathrm{~m}^{2}$. The results of the undertaken shows that Compositae, Gramineae, Fabaceae are the most representative of the surveyed one hundred twenty seven species of higher vascular plants from 29 families. Diversity on the southern slopes was more than on the northern ones. Species diversity is determined by the successions occurring spontaneously after a rough anthropogenic intervention, under the influence of such environmental factors as lighting, moisture, texture and richness of soil. The spectrum of life forms showed that the overwhelming majority according to K. Raunkiru are hemicryptophytes. Perennial herbaceous polycarpics are dominant in the spectrum of life forms, according to I.G. Serebryakov.
\end{abstract}

\section{Introduction}

A huge impact on the environment is resulted from the unfair exploitation of sand pits during which changes on the cycle of substances and energies, the dynamics of natural processes, the structure and productivity of bio-systems occur, and the species diversity of plants, also, gets lost. This impact is, clearly, embodied in land scenery, and changes in sand pits hydrogeological and climatic regime $[1,2,3]$. Under a good fitting set of circumstances, sand pits vegetation self-recovery will take not less than one hundred years $[4,5]$. Among the stages of reclamation, the biological stage, in the restorations process of sand pits vegetation

\footnotetext{
*Corresponding author: alaa_dabbagh@hotmail.com
} 
is considered to be the most important one [6]. In order to identify sustainable species that are promising for the restoration of disturbed lands, floristic studies are to be done.

Sand pits can be defined as unusual habitats with high substrate mobility and sharp fluctuations in temperature and water conditions of the slopes, a high degree of steepness, and with peculiar vegetation. It is similar to that characteristic of well-aerated, fine-grained substrates with a good washing regime [7]. Sand pits plants are adapted to life on moving sands: they are either covered with sand, or their underground organs are exposed [8]. To provide water and mineral nutrition a deep and highly branched root system were developed as a form of adaptation (for example, Artemisia vulgaris L.). Farther more it fixes it on a mobile substrate [9].

The aim of this research is to study sand pits plants bio-morphological characteristics in order to be used later on as the scientific basis for any project aiming at the restoration of vegetation cover of any disturbed land.

\section{Materials and methods}

The materials of our research have been collected from five sand pits located in different direction of Moscow region (Zvenigorodsky, Lyzlovo located in the west of Moscow and Dzerzhinsky, Ramensky, Lytkarinsky located in the southeast of Moscow). The Fixed Route method and the Geobotanical descriptions method were used; a list of vascular plant species was compiled in all above mentioned cites. Geobotanical descriptions on an area of $5 \times 5 \mathrm{~m}^{2}$, performed according to standard methods, located along the northern and southern slopes were the basis of the work. The total cover percentages of the found plants species determination, the dominant and subdominant species allocation and a list of species indicating the cover percentage, height and phenophase compilation were obtained through the implementation of the geobotanical description. K. Raunkier and I.G. Serebryakova life forms were adopted as the literature bases to perform the biomorphological analysis of the studied flora $[10,11]$.

\section{Results and Discussion}

\subsection{Species diversity of sand pits vegetation}

Insignificant species diversity of sand pits vegetation has been noticed. During 4 years, 127 species belonging to 29 families were found, which, in general, is common of sandy landscapes. Diversity ratio is consistent with Demina O.N. et al. [8]. Ten of the 127 species are adventitious plants for example Robinia pseudoacacia L. Acer negundo L. Beside the smooth progress of the landscape development (due to the rough technological intervention that has occurred), the number of species is determined also by the succession shifts under the influence of environmental factors, such as light, moisture and soil richness, and topological characteristics of the sand pits, of which steepness of the slopes can be mentioned. It should be noted that species diversity of southern exposure slopes, is higher compared to the northern exposure slopes. It is explained by habitat more contrasting conditions. A wide range of environmental factors (light exposure, soil moisture, etc.) allows more species of plants to settle on the southern slope.

Vascular plants grouped by families, growing in the Moscow region sand pits, are distributed unevenly. Compositae, Gramineae, Fabaceae are the largest number of species which fall within families ( Table 1). 
Table 1. Taxonomic spectrum of native species vascular plants of sand pits in the Moscow region.

\begin{tabular}{|c|l|l|l|l|l|}
\hline $\begin{array}{c}\text { Nr } \\
.\end{array}$ & Family name & $\begin{array}{l}\text { Number } \\
\text { of species }\end{array}$ & $\begin{array}{l}\text { \%of the total } \\
\text { number of species }\end{array}$ & $\begin{array}{l}\text { Number } \\
\text { of genera }\end{array}$ & $\begin{array}{l}\text { \% of the total } \\
\text { number of genera }\end{array}$ \\
\hline 1 & Compositae & 21 & 17.9 & 15 & 17.4 \\
\hline 2 & Gramineae & 19 & 16.2 & 14 & 16.3 \\
\hline 3 & Fabaceae & 14 & 12.0 & 7 & 8.1 \\
\hline 4 & Caryophyllaceae & 6 & 5.1 & 5 & 5.8 \\
\hline 5 & Polygonaceae & 6 & 5.1 & 2 & 2.2 \\
\hline 6 & Rosaceae & 6 & 5.1 & 4 & 4.6 \\
\hline 7 & Labiatae & 5 & 4.2 & 5 & 5.8 \\
\hline 8 & Scrophulariaceae & 5 & 4.2 & 4 & 4.6 \\
\hline 9 & Umbelliferae & 5 & 4.2 & 5 & 5.8 \\
\hline 10 & Cruciferae & 4 & 3.3 & 4 & 4.6 \\
\hline 11 & Salicaceae & 4 & 3.3 & 2 & 2.2 \\
\hline 12 & Betulaceae & 2 & 1.7 & 1 & 1.2 \\
\hline 13 & Hypericaceae & 2 & 1.7 & 1 & 1.2 \\
\hline 14 & Liliaceae & 2 & 1.7 & 2 & 2.2 \\
\hline 15 & Rubiaceae & 2 & 1.7 & 1 & 1.2 \\
\hline 16 & Boraginaceae & 1 & 0.9 & 1 & 1.2 \\
\hline 17 & Chenopodiáceae & 1 & 0.9 & 1 & 1.2 \\
\hline 18 & Cyperaceae & 1 & 0.9 & 1 & 1.2 \\
\hline 19 & Dipsacaceae & 1 & 0.9 & 1 & 1.2 \\
\hline 20 & Equisetaceae & 1 & 0.9 & 1 & 1.2 \\
\hline 21 & Oleaceae & 1 & 0.9 & 1 & 1.2 \\
\hline 22 & Onagraceae & 1 & 0.9 & 1 & 1.2 \\
\hline 23 & Pinaceae & 1 & 0.9 & 1 & 1.2 \\
\hline 24 & Plantaginaceae & 1 & 0.9 & 1 & 1.2 \\
\hline 25 & Primulaceae & 1 & 0.9 & 1.2 \\
\hline 26 & Ranunculaceae & 1 & 0.9 & $\mathbf{8 6}$ & $\mathbf{1 0 0}$ \\
\hline 27 & Ulmaceae & 1 & 0.9 & 1.2 \\
\hline 28 & Urticaceae & 1 & 0.9 & 1 & 1.2 \\
\hline 29 & Papaveraceae & 1 & 0.9 & $\mathbf{1 0 0}$ & 1.2 \\
\hline & Total & $\mathbf{1 1 7}$ & & 1 & \\
\hline
\end{tabular}

\subsection{K. Raunkiaer life forms spectrum of plants in sand pits}

A typical life form that dominates the phytocenoses of Central Russia is hemicryptophyte. Hemicryptophytes, according to the data obtained by the analysis of K. Raunkier life forms for plants of sand pits in the Moscow Region, dominate on the northern and southern slopes of the pits $(63 \%)$. They are well adapted even to the peculiar and often extreme growing conditions on the sandy substrate. (Fig.1). Hemicryptophytes rosette shoot serves successful wintering and also contributes to the economical use of energy. Such plants can begin to grow earlier. They make use of spring moisture efficiently and at the same time they avoid competition with stronger species [12]. 


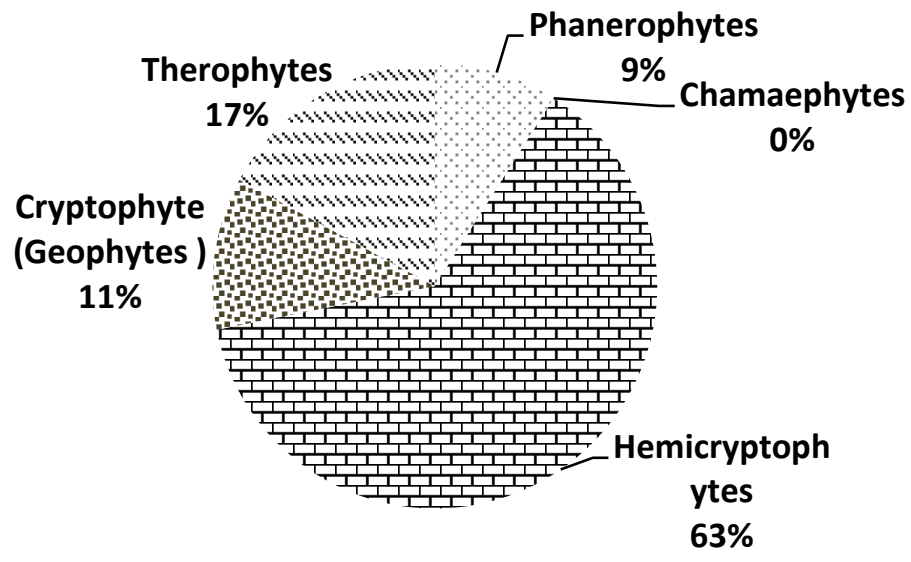

Fig. 1. Spectrum of life forms according to the system of K. Raunkiaer on different habitats.

Therophytes have a significant proportion (19 species, 17\%). In general and despite of the difficult environmental conditions of sand pits (strong lighting, sand movement, harsh winter conditions in the Moscow region), therophytes are actively undergoing unfavorable conditions in the form of seeds. They also actively take control over anthropogenic violated territories. Curiously, chamaephytes are completely absent in most of the sand pits. Such differences, most likely, are not associated with the exposure of the slopes but with vegetation species diversity, that spontaneously develops in each sand pit [13].

\subsection{I.G. Serebryakov life forms spectrum of plants in sand pits}

According to I.G. Serebryakov life forms spectrum, all sand pits were diferentiated by the predominance of perennial herbaceous polycarpics, among which large share of tap rooted plants Taraxacum officinale L., followed by long-rhizome Tussilago farfara L., then shortrhizome Artemisia vulgaris L. (Fig.2).

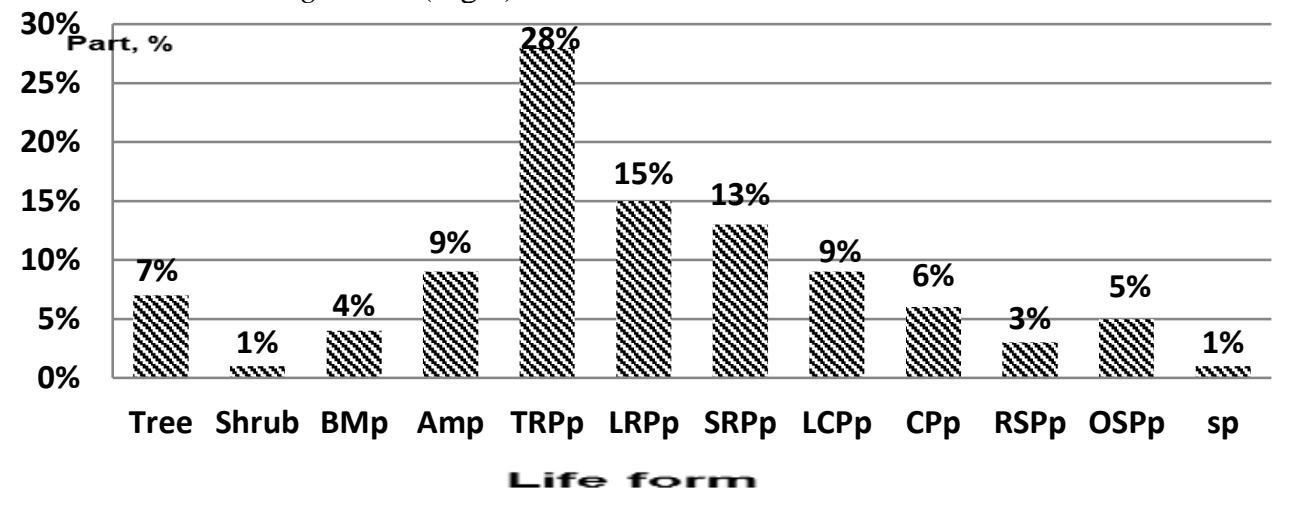

Fig.2. the spectrum of life forms by I. G. Serebryakov on different habitats

Notation keys: BMp - biennial monocarpic; Amp - annual monocarpic; TRPp - tap root polycarpic;

LRPp - long rhizome polycarpic; SRPp - short rhizome polycarpic; LCPp - loose cespitose polycarpic; $\mathrm{CPp}$ - creeping polycarpic; RSPp - root sucker polycarpic; OSPp - overground stoloniferous polycarpic; $\mathrm{Sp}$ - semishrub 
The dominance of tap rooted plants is, mainly, due to their ability to adapt to strong light conditions and resistance to drought, and the capability to get water from deep layers of the soil. Long and short rhizome plants tend to loose substrates and soft soils, although the latter are more adaptive to the growing conditions [14].

\section{Conclusions}

To sum up, it is worth mentioning that sand pits plants, perform a pioneering function; they bind sand grains, prevent or reduce substrate movement by forming subordinate roots and vegetative shoots, they quickly start growing after falling asleep with sand, have a branched or deeply penetrating root system, are resistant to drought and mechanical damage, can improve soil properties by holding it or enriching leaf litter, change wind intensity. The aforesaid conclusions can clearly answer our question "Do Diversity and Bio-morphological Spectrum of Psammophytes Matter in Restoring Vegetation of Sand Pits?" Theoretically, yes they matter, where implementation is left for further empirical research to answer the question.

Relying on the results of our research we recommend the use of herbal perennial plants to obtain vegetation on sand pits. They are able to form turf and prevent the movement of sand slopes quickly. Cereals are considered of primary importance, for example: Festuca rubra L. Bromopsis inermis (Leyss.) Holub. Festuca pratensis Huds. Agropyrum tenerum Vaseg. Dactylis glomerata L. Elymus fibrosus Schrenk. Elytrigia repens (L.) Nevski. Calamagrostis epigeios (L.) Roth. Phleum pratense L. In terms of appropriacy and importance, legumes occupy the second place. For example, Trifolium pratense L. Melilotus officinalis (L.) Pall. Trifolium hybridum L. Finally, oligotrophic species can be mentioned from the tree layer.

\section{References}

1. M.V. Makannikova, Z.A. Ionova, Recl. Of. Dist. Lands. E 2, 131 (2018)

2. F. Boscutti, A.Vianello, F. Bozzato, Rest. Eco. 25. E 4, 595 (2017)

3. O. Sumina, E. Koptseva, Cur. Tren. In. Land. Resear. E 3, 559 (2019)

4. R. Gentili, S. Sgorbati, C. Baroni, Rest. Eco. 101. E 19, 32 (2011)

5. A. Bradshaw, Land. And. Urb. Plan. 51, 89 (2000)

6. E. Diana, Ear. And. Env. Scien. 194 (092007) (2018)

7. L.A. Maslennikova, The psammophilic flora of the central part of the Volga Upland (PhD thesis, Moscow, 1999)

8. O.N. Demina, P.A. Dmitriev, L.L. Bul. Of. The. Sam. Scien. Cent. Of. The. Rus. Acad. Of. Scien. E 4, 1004 (2012)

9. B.A. Bykov, The main ecobiomorphs of desert plants of the Turan lowland (brief review) (Alma-Ata- Science, Moscow, 1987)

10. A.M. Aleinikova, E.A. Vanisova, E.Yu. Vasilieva, Study of natural ecosystems (House of RUDN Moscow, 2015)

11. Yu.E. Alekseev, P.Yu. Zhmylyov, E.A. Karpukhina, Plants of the city of Dubna (International University of Nature, Society and Man "Dubna", 2014)

12. N.A. Berezina, N.B. Afanas'eva, Plant ecology (Academa, Moscow, 2009)

13. О.В. Калашникова, Bul. Of. The. Sam. Scien. Cent. Of. The. Rus. Acad. E 1, 839 (2011)

14. H.T. Gajrabekov, S.B. Macaev, M.V. Geroeva. Vest. KrasGAU. E4, 128 (2012) 